\title{
Metamorfosis y transformaciones para vidas de perros: Cervantes a la luz del imaginario de Apuleyo y Luciano
}

\author{
Francisco J. Escobar BorRego*
}

\begin{abstract}
Resumen
El presente artículo ofrece un análisis circunscrito a la pervivencia de $E l$ Asno de oro en $E l$ Coloquio de los perros. Esta fuente clásica principal para Cervantes entra en correspondencia, además, con el imaginario creativo de Luciano. Dicho sincretismo estético arroja luz, en fin, sobre la cultura simbólica de Cervantes a partir de categorías conceptuales como metamorfosis y transformaciones.
\end{abstract}

Palabras clave: Cervantes; El Coloquio de los perros; Apuleyo; El Asno de oro; Luciano; animales; cultura simbólica.

Title: Metamorphosis and Transformations for Dogs' Lives: Cervantes in the Light of the Imaginary of Apuleius and Lucian

\begin{abstract}
This article offers an analysis circumscribed to the survival of The Golden Ass in The Dialogue of the Dogs. This main classical source for Cervantes has its correspondence, in addition, in Luciano's creative imaginary. This aesthetic syncretism sheds light, finally, on the symbolic culture of Cervantes from conceptual categories such as metamorphosis and transformations.
\end{abstract}

Keywords: Cervantes; The Dialogue of the Dogs; Apuleius; The Golden Ass; Lucian; Animals; Symbolic Culture.

* Universidad de Sevilla.fescobar@us.es / ORCID iD: https://orcid.org/0000-0001-5400-2712. 


\section{Cómo citar este artículo / Citation}

Escobar Borrego, Francisco J. 2020. «Metamorfosis y transformaciones para vidas de perros: Cervantes a la luz del imaginario de Apuleyo y Luciano». Anales Cervantinos 52: 227-253, https://doi.org/10.3989/anacervantinos.2020.009.

\section{REBUZNE EL PÍCARO O VIDAS DE PERROS: EL PENSAMIENTO FILOSÓFICO De Cervantes y los ARQuetipos de la nOvela antigua}

Bien conocida es, en la conformación y forja de la poética narrativa cervantina, la armonización que practicó don Miguel entre tradición clásica, pensamiento filosófico y novela antigua, en la que Apuleyo ocupó un lugar preeminente entre sus modelos predilectos. Baste recordar El Coloquio de los perros, en diálogo con El casamiento engañoso como historia marco, recurso muy apuleyano por cierto, para comprobarlo: «Novela y coloquio que pasó entre Cipión y Berganza, perros del hospital de la Resurrección, que está en la ciudad de Valladolid, fuera de la puerta del Campo, a quien comúnmente llaman los perros de Mahúdes» ${ }^{1}$. Como se ve, más allá de que Berganza constituya a buen seguro el alter ego de Cervantes como autor caché u oculto y Cipión, en recuerdo a Escipión, el crítico, resulta clara la hibridación entre la novela dialógica y el coloquio de tradición erasmiana, en entronque, además, con la tradición lucianesca, apuleyana y platónica. De hecho, de Platón bebe Apuleyo, relacionado, a su vez, por la historia del asno con el cínico Luciano, según se indica en el argumento del séptimo libro de El Asno de oro, romanceado por el arcediano hispalense Diego López de Cortegana, que leyeron Cervantes, Góngora, Lope de Vega y otros egregios ingenios áureos ${ }^{2}$.

Pues bien, otra de las modalidades genológicas que Cervantes asimiló en virtud de su granado conocimiento de la tradición clásica y el pensamiento filosófico de la Antigüedad viene dado por la vida en calidad de género literario, con resonancias de Plutarco ${ }^{3}$. Sin embargo, siguió también la senda conceptual desde el prisma de las vidas de hombres ilustres de Petrarca, redactadas a partir de 1337 y brindadas a Francesco da Carrara, hasta otras señeras obras del humanismo europeo como el Elogio de la locura de Erasmo,

1. Cervantes $(2010,650)$. En cuanto al estado de la cuestión para el presente objeto de estudio: Cárdenas-Rotunno (2016), Vivar (2016), D’Onofrio (2018) y Brioso (2020).

2. Tengo en cuenta para los pasajes de El Asno de oro: Apuleyo (2019). En cuanto al filósofo cínico de Samósata: Luciano $(1998,2013)$; y en lo referente a la pervivencia áurea de Apuleyo y Luciano: García Gual (2013) y Núñez Rivera (2015).

3. Sáez (2014, 2015). 
con prólogo dedicado a Tomás Moro, y la vida de este por Fernando de Herrera.

En cualquier caso, Cervantes se sirvió de esta categoría conceptual hasta el punto de que Berganza llega a relatar su vida mientras que Cipión promete narrar la suya, aunque esto no se produzca. Para ello tuvo en cuenta, en fin, estilemas que atañen a la autorrepresentación o rúbrica autorial, de manera que el autor puede llegar a intervenir como personaje de ficción en su historia novelada; por ejemplo, desde El Quijote, I, 6, o el prólogo de las Novelas ejemplares (1613), así como el Viaje del Parnaso y Adjunta al Parnaso (1614), a modo de broche a esta línea conceptual de visible experimentación narrativa.

Pero además, en lo que atañe a El Coloquio de los perros, la tradición clásica, y en concreto la novela antigua, brindaba otros precedentes para la picaresca y estas vidas de perros, más allá de la vida de asno de Apuleyo; es el caso del Satiricón de Petronio, del siglo I d. C., aunque sin repercusión prácticamente en el canon genérico español, salvo una traducción de J. Pellicer (1623) y una tardía edición del banquete de Trimalción de 1664. En cambio, en Italia sí se había difundido el ars narrandi de Petronio en impresos de 1482, en Milán, y de 1499, en Venecia. Sea como fuere, la transformación asociada a perros y asnos, con el tema picaresco del hambre como denominador común, se encuentra en El Asno de oro; en concreto, en VII, 3, cobrando visible presencia Lucio, en tanto que la imagen de los perros se identifica en esta misma obra, así en II, 1, cuando el protagonista se propone describir una estatua de Diana acompañada de sus perros que parecían verdaderamente vivos. Es más, la metamorfosis vinculada a otras formas de animales, aunque sea en apariencia metafórica pero que encubre en realidad la naturaleza humana, la hallamos en El Asno de oro, VIII, 3, en el episodio del echacuervos de la diosa Siria; o lo que es lo mismo, estamos ante elementos narrativos entre realidad y ficción procedentes de la novela antigua con los que Cervantes debió experimentar cierta empatía connotativa, como se comprueba en El Asno de oro, IV, 2, por el tema del cautivo y con lesión en el brazo de por medio, en un contexto bélico en el que se refiere la pérdida de dos capitanes en Beocia.

Ahora bien, en consonancia con esta fértil tradición filosófico-literaria, prima en la forja de la poética narrativa de Cervantes el principio de verosimilitud conforme al «mostrar con propiedad un desatino». Y es que dicho ideario resulta característico de la novela antigua, estando asociado al placentero deleite de la diversión en virtud de la parodia compleja, como manifiesta Luciano en los primeros compases de su Historia verdadera, concretamente en el prólogo. De otro lado, el autor «cínico» vuelve a recuperar esta sátira a los filósofos como leitmotiv en relatos del calado de Icaromenipo o Menipo en los cielos, cuyo protagonista es el cínico Menipo, prefiguración, al fin y al cabo, de otros lugares paralelos cervantinos, con utopía al fondo: el viaje de Clavileño a las esferas celestes, de raigambre ariostesca, y el sueño de don Quijote en la Cueva de Montesinos, al abrigo y socaire del ciclo 
carolingio ${ }^{4}$, hasta los viajes fabulosos y trufados de peripecias en el Persiles, en una épica novelesca en prosa alentada por su emulación de Heliodoro pero ya identificable en El Asno de oro.

Por tanto, cabe poner de relieve, de entrada, que Cervantes marida para sus vidas de perros, o asnos según se mire, el apuleyanismo vigente en nuestra tradición literaria de personajes marginales y excluidos de la élite social en obras tan aclamadas como La Celestina (véase más abajo), y la pervivencia de Luciano en el humanismo europeo. De hecho, la estela de este último autor de notorio abolengo filosófico-dialogístico arranca hacia 1500, prolongándose hasta 1550, bajo el prisma humanístico canónico de dos preclaros lectores de Apuleyo: Erasmo y Tomás Moro. Con el tiempo, se produce paulatinamente cierta atenuación de su vigencia entre 1550 y 1600 , para, por fin, revitalizarse entre 1600 y 1650 con una vuelta a la tradición primigenia, contexto en el que se viene a ubicar El Coloquio de los perros, con énfasis en los sueños hasta culminar con una obra tan representativa como los Sueños, de Francisco de Quevedo. Además, en este marco general, hay que destacar, sobre todo, las aportaciones, como he referido, de Erasmo y Moro entre 1504 y 1514, con una edición de Luciano, aunque sin la Historia verdadera o Relatos verídicos, las Opera omnia (1538) de Luciano por Micilo, editadas en Heidelberg, pero especialmente el aporte de Poggio Bracciolini en armonía con otras traducciones italianas de mediados de siglo. Por tales razones, estas habrán de propiciar el calado lucianesco en el humanismo español, con intérpretes y recreadores de la altura de Francisco de Enzinas o Juan de Vergara, en tanto que la enseñanza de Luciano se hará una constante en la ratio studiorum de los jesuitas.

Sea como fuere, lo cierto es que, en consonancia con El Asno de oro, asistimos a una manifiesta armonización entre su «pícaro rebuzno» y la tradición lucianesca, con el pensamiento filosófico de los cínicos de por medio. Por lo demás, estos filósofos, que sustentaban sus juicios sobre la crítica satírica (parrasía), la desfachatez (anaídeia) y la indiferencia (adiaphoría), fueron objetos de semblanzas biográficas, redactadas por Diógenes Laercio en sus Vidas y opiniones de los filósofos más ilustres o Vidas de filósofos ${ }^{5}$. De hecho, si hay un filósofo que es necesario recordar en particular este es, sin duda, Diógenes el Perro, por su libertina mordacidad de palabra o parresía. Tanto es así que se reconoce retratado en los Diálogos de los muertos de Luciano, de indiscutible influencia en los hermanos Alfonso y Juan de Valdés tras la estela de filiación erasmista, como también los Diálogos de los dioses, Menipo, Caronte y otras obras suyas. Sin embargo, el asno «filósofo», con vida de perro y un toque ciertamente "cínico», se encontraba ya en el relato de Apuleyo; en concreto, en X, 6, en el episodio de las fiestas de Corinto.

4. Percas de Ponseti (1980) y Egido (1994); para otros aspectos complementarios: Marasso (1954). En cuanto a sátira y picaresca: Ruiz Pérez (1996, 2011), Darnis (2014, 2015) y Darnis et al. (2017).

5. Laercio (2009); también Blanco (2012). 
Pero profundicemos en estas vidas de perros o asnos filósofos al trasluz del apuleyanismo hispalense.

\section{LOS PERROS (ASNOS) FILÓSOFOS Y EL DISCURSO DE LA VIDA: CON LUCIANO Y EL APULEYANISMO HISPALENSE DE FONDO}

Como es sabido, el «discurso de mi vida» constituye un leitmotiv cervantino que está vinculado a su concepto de amistad, según se comprueba en el prólogo de las Novelas ejemplares, si bien con resonancias en los perros o asnos filósofos de El Coloquio ${ }^{6}$. De hecho, baste recordar el deseo de hablar que estos perros evidencian y su prodigiosa memoria como facultad del entendimiento hasta el punto de que el lector asiste a la petición de Cipión para que Berganza relate con detenimiento su vida ${ }^{7}$, mientras que Berganza le promete, por su parte, contar la suya a modo de correspondencia, aunque finalmente no sucederá. En otras palabras, la extrañeza ante la facultad parlante del perro, incluyendo su capacidad de raciocinio lógico para la evocación ordenada y sistemática de los episodios de su vida, viene a constituir un verdadero leitmotiv a lo largo de El Coloquio, con especial énfasis en la memoria. Al tiempo, se incluye el ideal metaliterario cervantino en correspondencia con El Quijote II, 44: «Pide no se desprecie su trabajo, y se le den alabanzas, no por lo que escribe, sino por lo que ha dejado de escribir» ${ }^{8}$.

$\mathrm{Y}$ es que el inicio autobiográfico de la pícara vida de perros de Berganza radica y cobra carta de naturaleza en Sevilla, enclave medular para el apuleyanismo en España y donde arrancará su aprendizaje al compás maestro de experimentados amos a los que habrá de superar en astucia ${ }^{9}$; esto es, tras la zaga de Lázaro de Tormes, alentado por la tradición «picaresca» avant la lettre del asno filósofo. Se trata, por ende, de un capítulo cardinal de nuestra prosa de ficción áurea en la que no habrán de faltar, por añadidura, sabrosas notas de etología remozadas de sabor picaresco desde El Asno de oro hasta el Lazarillo y sus continuadores; entre ellos, el Lazarillo metamorfoseado en atún de la anónima Segunda parte del Lazarillo (Amberes, 1555), con maridaje e imbricación respecto a la alargada estela apuleyano-lucianesca ${ }^{10}$.

En efecto, en el dilatado relato de esta vida perruna de Berganza, Cervantes tiene muy en cuenta su sutil modulación, desde los primeros compases, hacia la historia de brujas y artes mágicas, o sea, como en El Asno de oro, al que acabará finalmente aludiendo; o lo que es lo mismo, mediante una referencia intratextual en el ordo artificialis narrativo («si no fuera por lo que después te diré»), en alusión al atractivo episodio de la bruja Cañizares, quien

6. Cervantes $(2010,651-652)$.

7. Cervantes $(2010,652)$.

8. Cervantes $(2010,663)$.

9. Cervantes (2010, 653); también: Brioso (1998a, 1998b) y Gómez Canseco (2013).

10. Mascarell (2011). 
entrará en escena más adelante. Seguidamente, prosiguiendo el azaroso relato de su vida, Berganza decide centrar su atención en la cotidianidad picaresca del matadero sevillano, en el que no están ausentes, claro está, ni los jiferos ni los rufianes ${ }^{11}$. De hecho, el perro «filósofo», tras sus peregrinas aventuras y desgraciados escarceos pastoriles, acabará regresando de nuevo a Sevilla ${ }^{12}$; por tanto, una categoría espacial significativa para Cervantes no solo por sus estrechos lazos personales y profesionales en dicha ciudad sino también por su integración e inmersión en un marco sociocultural en el que se estaba difundiendo por entonces el «pícaro rebuzno» del asno filósofo, llamado Lucio, homónimo del autor: Lucio Apuleyo.

Asimismo, esta notoria inclinación de Cervantes por la vida picaresca sevillana, con la que se llega a familiarizar Berganza, viene a explicar la topografía literaria en la que tampoco se soslaya la alusión al «estudio de la Compañía de Jesús» cuando Berganza servía al mercader, con la ratio studiorum y los ejercicios espirituales de san Ignacio al fondo ${ }^{13}$. Además, se traen a colación otros destacados enclaves sevillanos como la plaza de San Francisco o «los barrios de San Julián», lugar próximo a la Macarena ${ }^{14}$, así como la Puerta de Jerez, el Colegio Mayor de Santa María de Jesús, fundado por el maese Rodrigo Fernández de Santaella, pero también, a modo de contrapunto para la vida de la ciudad, entre Jerusalén y una nueva Babilonia renacida, el universo rufianesco y picaresco del hampa ${ }^{15}$.

En este contexto no podía faltar, claro está, la descripción del patio picaresco de Monipodio, por tanto en diálogo intertextual con Rinconete y Cortadillo, aunque ahora desde la perspectiva o hipotiposis de Berganza al hilo de la vida de Colindres, en la que se evoca, en las fronteras entre la realidad y la ficción, la cárcel de Sevilla donde estuvo preso nuestro escritor ${ }^{16}$. Por ello, tras narrar la ruidosa y movida pendencia de su amo con unos rufianes en la Puerta de Jerez, decide mencionar Berganza la casa y patio de Monipodio, ubicados frente a la Torre del Oro, en la antigua calle de la Cruz; o, como se dice en consonancia con una jácara, género coreográfico-musical por excelencia para la picaresca, junto al Molino de la Pólvora. De hecho, sobresalen, a propósito de dicho efecto coreográfico-performativo, visibles gesticulaciones escenificadas como si conformaran una ficcionalización de la destreza y tretas de esgrima ${ }^{17}$, con correspondencia en El Quijote y según se indica técnicamente en la Filosofía de las armas de Jerónimo Sánchez de Carranza $^{18}$, buen conocedor tanto de la picaresca como de las almadrabas de atunes. Incluso en consonancia con lo expuesto, Cervantes, en su pasaje,

11. Cervantes (2010, 653-655).

12. Cervantes (2010, 665-667).

13. Cervantes $(2010,669)$.

14. Cervantes $(2010,693)$.

15. Cervantes $(2010,689)$.

16. Cervantes (2010, 686-688).

17. Cervantes (2010, 690-691).

18. Escobar (2015a, 2015b). 
propone, al tiempo, una meditada reflexión metaliteraria sobre el modo autobiográfico del género picaresco heredado de la novela antigua, fundamentalmente de Apuleyo, desde la censura crítica de Cipión, quien modera y llega a dirigir el discurso de la vida de Berganza ${ }^{19}$.

En síntesis, tras esta relumbrante y fulgurante estela del apuleyanismo hispalense, cabe destacar cum grano salis la idea o noción conceptual de Cervantes en Sevilla y la Sevilla de Cervantes en su imaginario narrativo de novela urbana para otra picaresca. Ello es así habida cuenta de la indiscutible relevancia del contexto sevillano en estas historias de pícaros, incluyendo al autor hispalense Mateo Alemán y su exitoso Guzmán de Alfarache como género literario-editorial. En cualquier caso, en dicha cartografía real y ficticia (topotesia), el lector continúa hallando, hasta la fecha, un retal inacabable de imágenes plurales y dialogantes entre vida y literatura al hilo de una nueva Roma y sacra Jerusalén; o lo que es lo mismo, con comedias de santos y estampas hagiográficas en aras de acogerse a sagrado, pero también como una cruda Babilonia destinada a vidas de perros, aunque estén protagonizadas por filósofos cínicos.

Por lo demás, el elenco o galería de retratos, bien prosopográficos o con pátina de etopeya, que desfilan, gracias a Cervantes, por los distintos espacios literarios de Sevilla, así la Cárcel Real y la Casa de los locos, La Puerta de la Carne y el Matadero, las Barbacanas y el arrabal de Triana o el Baratillo, resulta infinito: Monipodio y la cofradía del latrocinio, Rinconete y Cortadillo aspirantes a pícaros, tahúres y peruleros, avispones, rufianes dichosos y valentones, la vieja Pipota, Escalanta, Cariharta en y al Compás de la Mancebía..., entre supersticiones, devociones, beaterías y supercherías. Asistimos, en resumidas cuentas, a un inacabable macrocosmos presidido por los negocios y el lucro mundano entre naves y el Puerto, el comercio con América, el Guadalquivir y el Arenal, los robos de capa, la Casa de Contratación...; en definitiva, el germen de otra picaresca en la mesa de trucos o tropelía cervantina $^{20}$.

Pero, además, Cervantes decidió incluir academias contrahechas y fingidas en clave de ironía paródica, como la Argamasilla, en una ciudad, la de Sevilla, que fue cuna del apuleyanismo español en círculos de élite o lieux $d u$ savoir, y que contó con señeros modelos precedentes para nuestro autor. Entre ellos destaco, a propósito de sus fuentes de referencia, a Gutierre de Cetina, autor de un ciclo de octavas en castellano dedicadas al mito apuleyano de Psique a partir de un importante conjunto de grabados italianos ${ }^{21}$ : otra historia de vida, metamorfosis y conversiones espirituales en calidad de reflejo especular de la de Lucio en El Asno de oro. Asimismo, en una continuación de esta rica tradición hispalense, vendrá a sobresalir igualmente el erudito proyecto épico-novelesco de aliento apuleyano, bajo el temperamentum del

19. Cervantes (2010, 655-656).

20. Jiménez Heffernan (2008).

21. Escobar $(2000,2002)$. 
canon de Ferrara, fraguado y ensayado en el seno de la academia de Juan de Mal Lara, con La Psyche ${ }^{22}$, Fernando de Herrera, Cristóbal Mosquera de Figueroa o Jerónimo Sánchez de Carranza; por tanto, ciudad no solo apta para vidas de perros sino también para vidas de asnos y otras literaturas de metamorfosis y transformaciones.

En efecto, en esta ciudad entre luces y sombras, como el claroscuro pictórico y cartográfico de las estampas cervantinas en El Coloquio de los perros o Rinconete y Cortadillo, había visto la luz la editio princeps de la traslación al castellano de El Asno de oro (Sevilla, Jacobo Cromberger, 1513) por Diego López de Cortegana, inquisidor instalado en el Castillo de San Jorge, próximo al Puente de barcas, que experimentó, en su etapa de senectud, una conversión o metamorfosis espiritual, como la de Lucio o Psique, alentado como autor caché al calor humano de las letras traduciendo a Apuleyo, Erasmo, Picolomini y otros auctores cumbres de la literatura universal que sobresalieron por su pensamiento estético-filosófico.

Sea como fuere, habida cuenta del manifiesto éxito de esta traducción, y ciertamente hasta tiempos de Cervantes, Lope de Vega y Góngora, no es de extrañar que rebuznase el asno... y bien; y es que Cervantes resultó ser un hábil lector y recreador oculto de Apuleyo tanto en El Quijote, además de El casamiento engañoso y El Coloquio de los perros, como en el Persiles, épica en prosa novelesca a pique de darse a la estampa con las vidas de papel de Periandro y Auristela, según recuerda en su autorretrato, vida de arte y testamento de vida literaria representados en El viaje del Parnaso; en otras palabras, todavía con anhelo de emulación respecto a Heliodoro, Aquiles Tacio y seguramente hasta su amigo y enemigo, valga el oxímoron, Lope de Vega con El peregrino en su patria, de 1604, arranque de la desavenencia entre los dos ingenios tan cercanos al concepto de vida y literatura, así como de realidad y ficción.

En suma, tras las huellas de Cervantes en Sevilla, se pone de manifiesto que queda todavía mucho por indagar sobre el resonante rebuzno del pícaro de oro, incluyendo el juego simbólico a propósito del valor de los diferentes metales ensayado en clave conceptual tanto por López de Cortegana como por el humanista Juan Partenio Tovar en los preliminares de la traducción de El Asno de oro, acompañados de una vida de Apuleyo en la ordinatio del texto como accessus ad auctorem por mímesis para con el primer comentarista de El Asno de oro: el editor boloñés Filippo Beroaldo.

Son claves literarias, en definitiva, que se fueron gestando al calor del apuleyanismo hispalense hasta el punto de que hay que contextualizar, en esta estela conceptual, la vida de un pícaro bravucón en un libro, similar a la de Ginés de Pasamonte, en la referida Filosofia de las armas de Jerónimo Sánchez de Carranza. De hecho, este atento lector de El Asno de oro en el círculo apuleyanista hispalense, «deudo» de Mal Lara y elogiado por Cervantes en

22. Mal Lara (2015a); para la modalidad épico-novelesca en Cervantes con Sevilla al fondo: Escobar (2018a). 
el Canto de Calíope, en su Filosofía de las armas viene a recrear, en un contrapunto entre la realidad picaresca y una utopía entre «soledades», un maestro de esgrima poco cuerdo y bravucón, en tanto que se alude a las ininterrumpidas lecturas de libros de caballerías y otros géneros afines; e incluso, más allá de la implementación científica del arte de destreza con propiedades geométricas y tecnicismos como «treta», con resonancias que llegarán hasta el Buscón, se menciona, en el transcurso de la ficción dialogístico-narrativa, la promesa de una vida al modo autobiográfico al igual que en el caso cervantino de Ginés de Pasamonte, recuérdese, con robo de rucio de por medio; en fin, «rebuzne el pícaro», una vez más ${ }^{23}$.

En otras palabras, estamos ante atentos lectores y recreadores de las $\mathrm{Me}$ tamorfosis de Apuleyo desde Sevilla a Sanlúcar de Barrameda, como sabía Cervantes teniendo en calidad de amigo común a Cristóbal Mosquera de Figueroa, integrado de pleno en este círculo de élite, con otras transformaciones afines previas en la tradición literaria en el entorno de Medina Sidonia, según dan buena prueba de ello Lázaro atún, entre la tradición clásica y la vertiente folclórica, y las almadrabas en la Segunda parte del Lazarillo; o lo que es lo mismo, en consonancia con el apuleyanismo hispalense y otras obras de aliento lucianesco de la altura estética de El Crotalón y el Viaje de Turquía.

\section{LA OTRA PICARESCA DE CERVANTES Y SU POÉTICA EJEMPLAR: CONTEXTO HISTORIOGRÁFICO Y CANON PARA VIDAS DE PERROS (Y ASNOS)}

A la vista de lo expuesto hasta el momento sobre Apuleyo romanceado por López de Cortegana, se puede llegar a la conclusión de que Cervantes leyó atentamente un asno filósofo moralizado conforme a una vida ejemplar, pero en armonía, al tiempo, con la vida del autor africano vinculada a la magia. De otra parte, la alusión apuleyana a Hipata en Tesalia, tierra de magia y brujería, como cronotopo para el viaje iniciático y arranque del libro, según pudo advertir Cervantes, resulta ser coincidente, además, con Lucio o El asno de Luciano, si bien otras claves en diálogo intertextual con los preliminares vienen a arrojar luz para la presencia de la magia en El Coloquio de los perros. De entrada, el personaje de Palestra, con la que acabará manteniendo una relación sexual Lucio en El Asno de oro, y la curiosidad impertinente de este

23. La popularidad de Carranza, al hilo de su sincretismo apuleyano-lucianesco con odres y asnos de por medio, queda puesta de manifiesto en una conocida obra de Lope de Vega que atesora un visible sabor apuleyano: La viuda valenciana (vid. infra), redactada en el período comprendido entre 1595 y 1600, e impresa en 1620 en la XIV parte de las Comedias. De hecho, La viuda valenciana recrea el motivo de los odres de vino, identificable tanto en El Asno de oro como en El Quijote, y hasta con reminiscencias en el autor de La vida del Buscón (vv. 1757-1764; Lope de Vega 2001, 226-227). Es más, en La viuda valenciana Lope llega a aludir a Cervantes, en las fronteras entre la realidad y la ficción, y a La Galatea (vv. 845-851; Lope de Vega 2001, 162), por tanto, como en el donoso escrutinio y El Coloquio de los perros. 
por aprender las artes mágicas en aras de realizar prodigios, metamorfosis y transformaciones, están presentes en Lucio o El asno. Por ello, en tal simbiosis estético-conceptual entre apuleyanismo y pervivencia lucianesca, la hechicera lasciva, mujer de Hiparco, que transforma a los hombres en animales conforme a sus deseos, tiene correspondencia intertextual en El Coloquio de los perros, del mismo modo que en El Asno de oro, Palestra será quien le enseñe al protagonista cómo su ama realizaba peligrosas prácticas de brujería.

Es más, Cervantes se propuso entroncar con una fructífera tradición literaria en nuestras letras españolas que conectaba al mago Apuleyo y a su protagonista Lucio, víctima de estas arriesgadas prácticas, con otro personaje picaresco y de malas artes de finales del siglo XV: Celestina, recreada bajo la rúbrica autorial de Fernando de Rojas en la obra homónima de 1499; por ejemplo, en las conocidas palabras de Pármeno: «¡Allá yrás con el diablo tú y malos años! ¡Y en tal hora comieses el diacitrón como Apuleyo el veneno que le convirtió en asno!» ${ }^{24}$. De hecho, esta obra abría, con vistas a la primera mitad del siglo XVI, una dilatada senda para la pervivencia apuleyana y su prefiguración picaresca in nuce, contando ya con la versión romanceada y ejemplar de López de Cortegana desde 1513. Y es que se distinguen, en este señero elenco, nombres tan destacados como el de Gonzalo Fernández de Oviedo, Historia general y natural de las Indias (1526), obra en la que se recuerdan las versiones dedicadas al asno tanto de Luciano como de Apuleyo, incluyendo el ungüento mágico y el antídoto de las rosas ${ }^{25}$, o el de Francisco Delicado con La Lozana andaluza o Retrato de la Lozana andaluza en lengua española muy clarísima, compuesto en Roma, el cual retrato demuestra lo que en Roma pasaba, y contiene munchas más cosas que la "Celestina» $(1528)^{26}$.

Por otra parte, durante la segunda mitad del siglo XVI, la fortuna y vigencia de Apuleyo se amplía gracias a las reediciones de la traducción de López de Cortegana. Baste recordar nombres tan señeros como los de Francisco Cervantes de Salazar, con su Apólogo de la Ociosidad y el Trabajo de Luis Mexía, glosado y moralizado... ${ }^{27}$, Pedro Mejía, ya sea en sus Diálogos o

24. Fernando de Rojas (1993, 399).

25. Puede leerse al respecto el libro VI, cap. 50, con cita de un avisado lector de Apuleyo, san Agustín, procedente de su De Ciuitate Dei, lib. XVIII, cap. 18, al hilo de «Quinta veritas, quod misterium demonum» (Fernández de Oviedo 1992, I, 219). Se trata, en efecto, de una imitación del preliminar «Lucio Luciano, natural de Patras» inserto en El Asno de oro que entronca con el pensamiento de san Agustín en calidad de auctoritas, al igual que en dicho paratexto, aunque ya con variación por parte de Fernández de Oviedo (Apuleyo 2019, 178-179). Por último, este preliminar, desde la editio princeps hispalense de Jacobo Cromberger, viene a ser traducción de una parte del prefacio de Filippo Beroaldo, concretamente la dedicada a la vida de Lucio Luciano (Apuleyo 2019, 462-463).

26. Delicado (2013, 6, 9-10, 13, 156, 233, 262, 300, 316-319, 325-326, 330-332, 335-338, 341 345, 347-350); además: Gil (1986).

27. Cervantes de Salazar (2012, 108). Las implicaciones simbólico-morales e iconográficas del asno apuleyano y el buey tienen sus resonancias en el Pensé que de la Filosofia cortesana (1587), de Alonso de Barros; en concreto, a propósito de «un asno echado» y la contraposición entre trabajo diligente vs. acidia (Lucero 2019, 165-166, n. 11). 
Coloquios (1547) ${ }^{28}$ o en la Silva de varia lección $(1550)^{29}$, y Juan de Arce de Otálora y sus Coloquios de Palatino y Pinciano (1550), con apuntes a las fábulas de «Isopo», o sea, como en El Coloquio de los perros, y varias citas a Apuleyo; entre estas: «... mucho más maravilloso es que Amonio Alejandrino, excelente filósofo, maestro de Orígenes y de Porfirio, tuvo por discípulo y oyente con ellos un asno, que aprendió filosofía; y Lucio Apuleyo, excelente filósofo, para ser admitido a los misterios de la diosa Isis, de filósofo se transformó en asno, escogiendo este animal por el más sancto y seguro» ${ }^{30}$. No faltan tampoco otras resonancias en La vida de Lazarillo de Tormes y de sus fortunas y adversidades (1554), claro está, así como en la Segunda parte del Lazarillo (1555), aunque con más influencia lucianesca, además de Juan de Timoneda, El Patrañuelo (1567), cuyo relato XX está especialmente inspirado en El Asno de oro, X, caps. 1 y $2^{31}$; Antonio de Torquemada, Jardín de flores curiosas (1569) y Sebastián de Horozco, Libro de los proverbios glosados (1570), con su apunte a la «... representación deste juicio de Paris [que] se escribe en Apuleyo, Del asno de oro en el libro 10, en el capítulo final» ${ }^{32}$; o incluso Juan de Pineda, Diálogos familiares de la agricultura cristiana (1589), en palabras de Filaletes ${ }^{33}$.

Ya en la primera mitad del siglo XVII, enclave cronológico en el que se inscriben El casamiento engañoso y El Coloquio de los perros, traigo a colación a Lope de Vega con El peregrino en su patria (1604), por ejemplo, «A lo menos la botica / del Escarmiento famosa, / que de Apuleyo la rosa / para medicina aplica // donde el doctor Desengaño / y el cirujano Vejez / remedian más de una vez / que el Peligro en todo un año» ${ }^{34}$; Francisco López de Úbeda en el «Prólogo» de La pícara Justina (1605), a propósito de Celestina y la tradición apuleyano-lucianesca referida a Momo, esto es, «Y ansí, no hay enredo en Celestina, chistes en Momo, simplezas en Lázaro, elegancia en Guevara, chistes en Eufrosina, enredos en Patrañuelo, cuentos en Asno de oro; y, generalmente, no hay cosa buena en romancero, comedia, ni poeta español cuya nata aquí no tenga y cuya quinta esencia no saque» ${ }^{35}$; Cristóbal Suárez de Figueroa, El pasajero (1617), en «... tenía por imposible esto de

28. Por ejemplo en IV, 2 (Mejía 2004, 451-452).

29. En II, 38, Mejía (1989, II, 795) llega a glosar un pasaje de El Asno de oro a partir de uno de sus temas principales: la fortuna. Asimismo, al hilo de Apuleyo y sus conocimientos de magia: III, 11 (Mejía 1989, II, 81-82); en lo que atañe a Florida: I, 18 (Mejía 1989, I, 338). Por último, seguramente la alusión, en IV, 1, a «Julio Pulley» (Mejía 1989, II, 312-313) se trate de una deformación fónicografemática del nombre de Apuleyo.

30. Arce de Otálora (1995, I, 34 y 219).

31. Ofrecen un análisis de la cuestión Sánchez Jiménez y Blanco (2014).

32. Sebastián de Horozco (1994, 144).

33. Con san Agustín como telón de fondo (Pineda 1963-1964, párrafo 1); por tanto, como en los preliminares de López de Cortegana en El Asno de oro.

34. Lope de Vega (2016, 493-494). De manera análoga, a propósito de Apuleyo y su Libro sobre la magia (Apología o Discurso sobre la magia XXIV, 1-4): Lope de Vega (2016, 356); en cuanto a Florida, VII, Lope $(2016,463)$ se sirve, una vez más, de Apuleyo en su mención de Alejandro.

35. López de Úbeda (2012, 189-190); del mismo modo en II, 2, 4, con ecos de López de Cortegana en el juego conceptual de «oro» y «lodo»: López de Úbeda $(2012,678)$. 
andar a pie, para cuyo remedio compré uno de aquellos [asnos] en quien tan de buena gana se transformó Apuleyo, de gentil presencia, mas de docientos de porte» ${ }^{36}$; una vez más Lope de Vega, en Rimas humanas y divinas del licenciado Tomé de Burguillos (1627), en concreto, tanto en el soneto «Si palos dais con ese palo hermoso», en el terceto final «En Tesalia los tuvo por regalos / el Asno de oro que compuso el griego: / tu bestia soy, Amor, dame de palos», como en los versos 83-87 de la canción «Ya pues que todo el mundo mis pasiones», o sea, «¿Qué Pangeo produce aquella rosa, / Astolfo del sentido de Apuleyo? / ¿Qué César, qué Pompeyo, / qué pastor, qué rocín, rucio o castaño, / no hirió tu flecha ni rindió tu engaño?»»37; Tirso de Molina, $L a$ huerta de Juan Fernández (1630), «Comprará / quien le ferie un Asno de oro / como el que Apuleyo pinta», con resonancias a propósito de las rosas del silencio $^{38}$; Luis Vélez de Guevara en El diablo cojuelo (1641), «... aquel que viene sobre el Asno de oro de Lucio Apuleyo es Creso, mayordomo mayor de la Fortuna, y a su mano izquierda, Astolfo, su caballerizo mayor» ${ }^{39}$; así como Baltasar Gracián en su Agudeza y arte de ingenio (1648), con alusiones a Apuleyo y a sus personajes, especialmente Psique ${ }^{40}$, y El Criticón (1651), en esta última obra con la mención a la «rosa del silencio» ${ }^{41}$, por tanto, como en Cervantes y El Coloquio de los perros, entre otros numerosos autores, si bien a partir de la segunda mitad del siglo XVII el floruit de la recepción de El Asno de oro acabará en paulatino declive. Esta es, en resumidas cuentas, la amplia y fértil tradición apuleyana, con modulaciones hacia Luciano y referencias a La Celestina, en la que Cervantes incardinó sus vidas de perros (o asnos).

Ahora bien, cabe advertir que el rebuzno del pícaro cervantino no se limitó, en modo alguno, a las Novelas ejemplares, representadas aquí tanto por $E l$ casamiento engañoso como por El Coloquio de los perros, sino que, en El Quijote, Cervantes se decantó por una imitación de Apuleyo más allá de que el término «Quijote» se hallase en la versión romanceada por López de Cortegana, en concreto en $\mathrm{XI}, 2^{42}$. Me refiero a su diálogo intertextual con $E l$ Asno de oro, III, 2, en alusión a la «industria», ardid o artificio, y otras resonancias respecto a El Quijote, I, 35, a propósito del episodio paródico de los

36. Cristóbal Suárez de Figueroa (1988, II, 443 y 454). Además de Suárez de Figueroa, destacan otras alusiones apuleyanas en Tomé Pinheiro da Veiga, Fastiginia o Fastos geniales (1605), al hilo de atractivos tapices en los que se representaban escenas populares de El Asno de oro; Sebastián de Covarrubias, Tesoro (1611); Diego López, Declaración de los «Emblemas» de Alciato (1615); o Baltasar Mateo Velázquez, El filósofo de aldea (1624), conversación I, con una referencia al libro I de El Asno de oro a propósito de un papagayo inexistente en la ficción de Apuleyo.

37. Lope de Vega (2005, 163 y 343); para otros pormenores: Ortega Garrido (2014).

38. Sobre las que volveré más adelante en el contexto narrativo de El Coloquio de los perros; véase por ahora: Tirso de Molina (1982, 83-84).

39. Vélez de Guevara $(1980,173)$.

40. Gracián (1993, 473, 654, 710, 737, 739-740, 758).

41. Desde la idea de Lucio Apuleyo como protagonista de El Asno de oro (I, Crisi XI; Gracián 1990, 260). En cuanto a la pervivencia de Apuleyo y Momo, como en La pícara Justina: III, Crisi séptima (Gracián 1990, 697).

42. López Estrada (2004). 
cueros u odres de vino y, claro está, en Donde se da fin a la novela del «Curioso impertinente» ${ }^{43}$, con paralelos temáticos para con La viuda valenciana de Lope de Vega, en virtud de una posible poligénesis y sus consiguientes loci communes apuleyanos ${ }^{44}$. Sea como fuere, al margen de estas analogías estéticas entre Cervantes y Lope, resulta claro que, a la luz del imaginario de $E l$ Quijote, reconocemos también las huellas del mago Apuleyo, a modo de impregnación, en el mágico Cervantes y su mesa de trucos o tropelía.

Sin embargo, será El Coloquio de los perros, en articulación narrativa con El casamiento engañoso, la novela más apuleyana y de aliento lucianesco de Cervantes, y a la que su distinguido autor le otorgó un tratamiento verdaderamente de realce e ideario conceptual. Así, en cuanto a la dispositio de las Novelas ejemplares como colección y conjunto de historias-cuentos, El Coloquio de los perros constituye la coda o remate musical polifónico. Es más, en lo que atañe a la narración de historias teniendo en cuenta un relato marco como el que proporciona El casamiento engañoso, sobresale en El Asno de oro la fábula que una anus relata a la joven Cárite, tras haber sido raptada por unos ladrones que moraban en una cueva. De hecho, esta anilis fabula se trata del cuento, novela o fábula de Psique y Cupido, que dejó su impronta en el Persiles ${ }^{45}$, cuya modulación como relato marco se localiza en los últimos compases de IV, 4 y prosigue desde IV, 5.

Pues bien, en este contexto narrativo apuleyano, por el que se decantó Cervantes, destaca la mención a las «visiones de los sueños» muy en consonancia con la tradición lucianesca, sobre todo cuando la vieja se dirige a Cárite en su sermocinatio o parlamento fingido. Por lo demás, su cierre tiene lugar al final de VI, 3, en cuyo colofón se integra de nuevo la narración de Lucio al modo autobiográfico. En otras palabras, estamos ante una técnica de novela marco similar a la que se halla implementada entre El casamiento engañoso y El Coloquio de los perros hasta el punto de que culmina su historia o «conseja» la anus con motivo de las bodas de Psique, ya inmortal, y Cupido $^{46}$. Luego proseguirá contando su vida de perros Lucio, pero no sin antes lamentar no tener a mano tinta y papel para de esta manera preservar mediante la escritura la historia que había escuchado oralmente. Sea como fuere, la necesidad por parte de Lucio de dejar constancia por escrito de los relatos a nivel de oralidad y sus distintas versiones se encuentra en otros pasajes de El Asno de oro; por ejemplo en el cierre de X, 1, en el que el protagonista manifiesta que, más allá de la cortedad del decir, ha hecho lo

43. Curiosidad impertinente apuntada ya en La Galatea pero análoga, al tiempo, a la apuleyana de Lucio y Psique. En cuanto a los pasajes del Quijote: Cervantes (1998, 415-417).

44. En palabras de Lisandro (vv. 475 y ss.; Lope de Vega 2001, 135-137).

45. Vid. infra. Esta fábula dejó su huella también, como he indicado, en La viuda valenciana. Por lo demás, en lo que atañe a la inversión del mito apuleyano en obras como esta de Lope o El conde Partinuplés de Ana Caro, en concreto, cuando el protagonista quebranta el tabú visual respecto a la invisibilidad de Rosaura, véase: De Armas (1976).

46. En paralelo a las felices nupcias tanto de Ruperta y Croriano como de Periandro y Auristela en el Persiles (Escobar 2007, 2008). 
posible por transcribir en el libro de su picaresca vida todo lo que pudo oír; por ende, de forma similar al modus operandi de Campuzano y su conciencia de redactar la experiencia vivida en lo que atañe al Coloquio «perruno» en su cartapacio.

Asimismo, en los episodios cervantinos que tejen la vida de perros del filósofo Berganza, otro marco literario destacado de transición que prepara la historia medular de la bruja resulta ser el del atambor ${ }^{47}$, habida cuenta de que vincula el personaje de Berganza, el perro sabio, a Cañizares. En este contexto, los rufianes hurtan al docto y prodigioso canino ${ }^{48}$, como también es robado el asno Lucio, incluyendo el símbolo humorístico de la cola que recuerda las controvertidas implicaciones temáticas en El Quijote respecto a Sancho y Ginés de Pasamonte, con yerros cervantinos de por medio, en un paralelo para con otro gran lector de Apuleyo: François Rabelais y sus vidas picarescas en Gargantúa y Pantagruel, con gigantes en calidad de protagonistas y parodia añadida de los libros de caballerías.

En cualquier caso, Cervantes vuelve a recrear dicho leitmotiv en El Coloquio cuando Berganza relata, con morosidad narrativa y en virtud de lugares comunes para con los preliminares de López de Cortegana y Partenio Tovar, la vida de los gitanos al hilo del asno rabón ${ }^{49}$. Tanto es así que el propio Berganza manifiesta asemejarse figuradamente a un asno, de manera que, al recordar a su amo poeta y autor de comedias, cuyo talento era merecedor del manteo como castigo, viene a sintetizar la narración de esta experiencia iniciática y la de otros amos, «en figuras fingidas y en bellezas de artificio y de transformación» ${ }^{50}$.

Es más, la necesidad de establecer un pacto de confianza con el interlocutor por parte de quien relata tan fabulosa historia, recurso bien cervantino por cierto, se localiza ya en El Asno de oro, I, 1; en concreto, cuando uno de los caminantes con los que se encuentra Lucio, Aristómenes, le ruega a este que dé crédito y carácter de veracidad a los episodios de magia de los que fue objeto su amigo Sócrates. De hecho, este último llega a enumerar la amplia aretalogía y malas artes de la maga, entre las que se halla, claro está, metamorfosear la naturaleza de los hombres en la de animales; o lo que es lo mismo, en un episodio de magia que se viene a desarrollar en el capítulo II del libro I, según se indica en su argumento, en correspondencia, al tiempo, con la focalización en la vida de perros desde la perspectiva narrativa de Campuzano, mientras que Peralta no puede dar crédito a la fabulosa y disparatada narración de su amigo ${ }^{51}$.

Por otra parte, como una modulación hacia la lectura y escucha atenta del perruno Coloquio por Campuzano y Peralta ${ }^{52}$, el sueño viene a cobrar prota-

47. Cervantes $(2010,694)$.

48. Cervantes $(2010,695-696)$.

49. Cervantes $(2010,720-721)$

50. Cervantes $(2010,727-730)$.

51. Cervantes $(2010,644-645)$

52. Cervantes $(2010,646-647)$. 
gonismo en la poética narrativa cervantina tras la estela apuleyana; así en $E l$ Asno de oro I, 2, en concreto, en el episodio de Sócrates y Aristómenes, con estado embriagador de por medio en lo que a los personajes se refiere. Del mismo modo, constituye para Apuleyo un leitmotiv de notable productividad habida cuenta de que Lucio llega a manifestar a Andria su necesidad de sueño reparador más que de hambre, puesto que conocía la miseria de Milón (I, 3); y más adelante, en II, 4, con alusión al sueño como imagen de la muerte (somnium imago mortis) y al canto de un gallo, junto a otros ejemplos identificables en III, 3; IV, 3; IV, 4 y X, 6.

Sea como fuere, al igual que los sueños, alude también Lucio a las patrañas relatadas por Milón (II, 2) en concordia igualmente con otros sueños o disparates; por tanto, en entronque con la rica tradición literaria de filiación lucianesca y erasmiana del coloquio, según se reconoce en el Diálogo de Mercurio y Carón de Alfonso de Valdés hasta El Coloquio de los perros y los Sueños de Quevedo, con el Bosco al fondo. Pues bien, en la segunda parte de la Historia verdadera, Luciano llega a recrear la Ciudad de los Sueños, contexto onírico en el que el propio autor, inserto en la ficción como personaje, le pide a Homero, en un caso de confluencia épico-novelesca ${ }^{53}$, que lleve a cabo un epigrama en el que se indica que va a regresar a su patria (nóstos); es decir, asistimos a una práctica similar a la semblanza biográfica que propone Cervantes en su prólogo a las Novelas ejemplares en diálogo con otras técnicas retóricas concomitantes en su época como la implementada por el pintor-poeta Francisco Pacheco en su conocido Libro de retratos. Además, el sueño o no-sueño, en el contexto temporal de la noche, cumple su función narrativa en otros diálogos de Luciano que fueron dejando su impronta en esta atractiva tradición estética en la que se incardinan las vidas de perros cervantinas. Me refiero al Icaromenipo y, en concreto, el pasaje en el que el cínico Menipo lleva a cabo una sermocinatio o parlamento fingido en un fugaz recuerdo a Ilíada, II, 1-2, con implicaciones conceptuales en El Coloquio, en un juego de espejos ${ }^{54}$, sobre todo en su cierre o coda final que dialoga con el broche de El casamiento engañoso; de hecho, está motivado por el interés narrativo del cuento de la vida de Cipión, aunque suspendido aquí pero prometido como una «segunda parte» de esta novela ${ }^{55}$, muy del gusto de Cervantes, al igual que sucede con La Galatea ${ }^{56}$.

Ahora bien, más allá de estas resonancias ecoicas de la tradición lucianesca y como estamos comprobando, El Coloquio de los perros resulta ser la obra más apuleyana de Cervantes, según se trasluce en el episodio sustentado sobre la magia. Como se recordará, los niños Cipión y Berganza, vástagos de la

53. A Homero precisamente evoca Cervantes en Quijote, II, 3, con un guiño épico-novelesco a propósito de Horacio, Ars poetica, 359 («quandoque bonus dormitat Homerus»).

54. Cervantes (2010, 652-653).

55. Cervantes (2010, 736-737). En cuanto a la Segunda parte del Coloquio de los perros (1635) de Ginés Carrillo Cerón: Madroñal (2011, 2012), con edición de la obra en 2013.

56. Cervantes (2014); para otros pormenores arcades, con música cervantina como colonna sonora: Escobar (2018b, 2018c, 2019a). 
bruja Montiela, han sido metamorfoseados en perros por las malas artes de la vengativa hechicera Camacha, con trasunto histórico en la cordobesa Camacha de Montilla. De esta suerte, la novella interpolada ofrece una alusión metanarrativa al inicio mediante ordo naturalis, presentado aquí in medias res ${ }^{57}$.

$\mathrm{Y}$ es que el concepto de novella vinculado a El Asno de oro estaba ya predestinado cuando Giovanni Boccaccio localizó en Monte Cassino, en 1355, un manuscrito del texto apuleyano, prefiguración de la editio princeps del texto latino en Roma, de 1469, así como de la edición crítica y con comento erudito de Filippo Beroaldo al filo de 1500, base textual e interpretativa para El Asno moralizado de López de Cortegana. Por lo demás, el Decamerón de Boccaccio atesora tres historias procedentes de Apuleyo mientras que su $\mathrm{Ge}$ nealogía de los dioses comprende el mito de Psique y Cupido, otra aclamada fábula de metamorfosis y transformaciones, a efectos de pervivencia y recepción áurea, que dejó su impronta en la estética narrativa de Cervantes.

Pues bien, de esta amplia estela novelística desde Apuleyo a Boccaccio, pasando por Beroaldo y López de Cortegana, un núcleo temático que interesó claramente a Cervantes viene dado por el protagonizado por las brujas que «se untan» durante sus arcanos rituales, como se colige de El Asno de oro. De hecho, tiene lugar en el relato de vida de Cañizares ${ }^{58}$ para más adelante pasar a describir la hechicera el ceremonioso ritual de las «unturas», que permitían las metamorfosis o transformaciones en otras naturalezas sorprendentes. Es decir, en una armonización de la voz narrativa de Berganza y la experiencia de Cañizares, habla primeramente el perro filósofo, movido por una curiosidad similar a la de Lucio, o sea, su curiosidad impertinente antes de transformarse en asno, en ambas versiones, la de Apuleyo y la de Luciano. Sin embargo, Cervantes llega a evocar otras metamorfosis posibles, por ejemplo en gallo y otras formas de aves ${ }^{59}$, según acaece en el relato dialogístico como sátira contra las ideas pitagóricas El gallo $o$ el sueño de Luciano. Por lo demás, en cuanto a la curiositas de Lucio en $E l$ Asno de oro, es el caso de III, 3, se trata de un episodio que leyó atentamente Cervantes con vistas a su tratamiento estético de la magia; esto es, cuando una vez finalizada la fiesta del dios de la risa, Andria le muestra a Lucio cómo su ama Pánfila practicaba las artes de una avezada hechicera.

En otras palabras, tales rituales y transformaciones por parte de las hechiceras, o «malas mujeres» como se anuncia en la portada del libro con resonancias misóginas desde Apuleyo a Boccaccio, se relatan efectivamente en El Asno de oro (II, 4), según se puede leer sobre todo en la narración de Theleforon a petición de Birrena en la que se alude, una vez más, al sueño, motivo o subtema recurrente en este tipo de ficciones. Más adelante proseguirá su relato Theleforon (II, 4), a propósito de «un gran sueño» echado por las «viejas encantadoras» por su «industria», concepto bien cervantino como se recordará en la historia de Basilio y Quiteria (Quijote II, XIX-XXI) hasta el punto de que da

57. Cervantes $(2010,701-703)$.

58. Cervantes $(2010,703-704)$.

59. Cervantes (2010, 709-712). 
la apariencia de que la persona está muerta, aunque no sea así en realidad. En cuanto a El Gallo de Luciano, asociado a la transformación de un hombre en gallo y otras metamorfosis en aves, merece la pena destacar el milagro del habla humana de este debido a un aparente encantamiento, aunque ha aprendido a ejercitar esta facultad por una causa que luego se desvelará. Además se identifican, en tal marco narrativo, el sueño y la noche en contraste con la luz del alba a modo de claroscuro, que anuncia el cierre del relato, y la retórica del silencio frente a la charlatanería, como deja ver El Coloquio. En fin, el hombre metamorfoseado en gallo en el relato de Luciano resulta ser Pitágoras, defensor de la transmigración de las almas o metempsícosis, por lo que estamos ante un gallo filósofo, al igual que los perros filósofos cervantinos.

Por último, cabe poner de relieve la preparación por Luciano del relato fabuloso e increíble contado por el Gallo a Micilo, quien es objeto de un sueño divino mientras se presta a proferir palabras satíricas y maledicentes, lo que constituye un visible paralelismo respecto al coloquio de Campuzano con Peralta en El casamiento engañoso. Al tiempo, el Gallo tiene como compañero a Hermes, de manera similar a Apolo en calidad de acompañante de Cervantes en el Viaje del Parnaso, en tanto que el alma del Gallo filósofo, Pitágoras, salió de Apolo y luego se reencarnó en diferentes formas, entre ellas, la de Aspasia y el cínico Crates. Asimismo, junto a la del gallo, la imagen de la lechuza y otras aves tiene su locus communis en el búho de El Asno de oro y de Lucio o El asno. Es decir, para este símbolo y otros elementos temáticos vinculados a la magia, el tropelista Cervantes se inspiró, una vez más, en el mago Apuleyo, entroncando, a su vez, con la tradición lucianesca. Tanto es así que, en el libro III de El Asno de oro, precisamente en el que se integra el famoso pasaje de los odres (III, 2) que inspiró a Cervantes en $E l$ Quijote por su curiosidad impertinente, se narra un episodio de brujería afín al cervantino, con huellas de otro gran catador y degustador apuleyano evocado por López de Cortegana en El Asno de oro moralizado: san Agustín y su De civitate Dei, XVIII, 18, 1. De esta forma se resalta en el Argumento, en el que se indica cómo Lucio fue objeto de un juicio, lo que trae a la memoria el episodio cervantino de Croriano y Ruperta en la épica en prosa o narración épico-novelesca del Persiles, motivado por una venganza y revestido de una notoria retórica forense-judicial.

Es más, en lo que a la dispositio se refiere, tras el episodio apuleyano de los odres en III, 2, los capítulos 3 y 4 se centran en esta transformación, metamorfosis o transfiguración por artes mágicas, según se refiere en el argumento correspondiente. Tanto es así que el lector, en III, 3, tiene acceso al laboratorio nigromántico de Pánfila, afín al de Celestina, como pudo advertir Cervantes ${ }^{60}$, en palabras de Andria a Lucio. Incluso el personaje de la alcahueta, bosquejado por López de Cortegana en su traducción, se localiza igualmente en El Asno de oro, IX, 4, al hilo del engaño de la taimada mujer del confiado tahonero con

60. Para la «herencia celestinesca» en el pensamiento estético de Cervantes puede leerse la edición de La tía fingida, al cuidado de Sáez (Cervantes 2019). 
un avisado amante, acabando el episodio con el trágico ahorcamiento del marido por «arte de encantamiento». Por lo demás, la curiosidad impertinente de Lucio, con correspondencia en su relato marco con la de Psique, incluye la cajita, bujeta o pyxis, que tiene su analogía complementaria en Lucio o El asno, al tiempo que ambos relatos coinciden, como he indicado, en la imagen y metamorfosis del búho, esto es, la lechuza mencionada en El Coloquio. Ahora bien, el personaje de Andria exhibe su analogía con el de Palestra, en tanto que en El Asno de oro, II, 1, Birrena advierte a Lucio de las malas artes de Pánfila, esposa de Milón, lo que no impide que en III, 3, Lucio le ruegue a su amante Andria que le enseñe las artes mágicas de su ama.

En efecto, en III, 4, Pánfila se dispone a embadurnarse de «ungüento» con el objeto de transformarse en búho mientras que Lucio, ayudado de su amante Andria, anhela experimentar per se dicha metamorfosis. Con todo, el protagonista, pese a «untarse» por mímesis respecto a Pánfila, no se convierte en el deseado búho sino en asno. Por tanto, este episodio, con magia y equívocos de por medio, debió divertir sobradamente a Cervantes hasta el punto de tenerlo en cuenta en El Coloquio. Además, según pudo advertir nuestro autor en su voluntad de maridar el apuleyanismo con la tradición lucianesca, el protagonista pretende experimentar esa transformación en ave, aunque se torcerá en una metamorfosis en burro, pese a haberse «untado», por tanto, al igual que se relata en El Coloquio, como si de un mago se tratase.

Pues bien, antes de la historia o cuento de los gitanos por Berganza, Cipión desea saber más sobre estas transformaciones, con un toque de magia (apuleyana), que resultaban ser consejas o cuentos de viejas; entre ellas, la del sacristán en jumento ${ }^{61}$, con resonancias, una vez más, de El Asno de oro, y con correspondencia temática para con La Gitanilla, en un juego de perspectivas como sucede con Monipodio. Sea como fuere, Cañizares, con aires celestinescos en su caracterización y sabedora de la trama, referirá la vuelta «a hombre» de Berganza ${ }^{62}$, con la duda de si de verdad tenía entendimiento («si es que acaso me entiendes» $)^{63}$, aunque antes llegue a evocar el antídoto de la rosa en El Asno de oro, que dejará su huella en El Coloquio ${ }^{64}$, como vamos a ver a continuación, en un apunte metaliterario de Cervantes, en calidad de autor caché, a su fuente.

\section{Cervantes metamorfoseado en el mago ApUleyo: rosas Del SILENCIO, TRANSFORMACIONES Y PROFECÍAS}

Como he venido apuntando hasta el momento, el símbolo de la rosa con función de antídoto se encuentra en El Asno de oro y en Lucio o El asno, en 
un nuevo sincretismo entre las dos fuentes que aprovechó Cervantes; así, en la primera de las obras en XI, 2, si bien se identifica ya en los preliminares, en concreto, en el Prohemio y otros textos. Pero además presenta su correspondencia respecto al cierre de Lucio o El asno, al decir de su protagonista en un repaso sintético de su vida para finalmente regresar a su patria (nóstos), tras recobrar su forma prístina. Con todo, acabará siendo rechazado por su amada porque le agradaba más, al parecer, con su aspecto de asno; por ende, en un broche inesperado humorístico, a modo de paraprosdokía, hasta el punto de que se cierra el episodio con el refrán «culo de un perro», evocado por Aristófanes en Acarnienses, 863 y Asambleístas, 255, y con la curiosidad del asno, una vez más, como leitmotiv concertante de la obra.

En cuanto a El Asno de oro, II, 3, se relata sobre este particular la «batalla de amores» entre Lucio y Andria con guirnalda de rosas de por medio, aunque el antídoto simbólico de las rosas reaparecerá en III, 4, cuando Lucio se haya metamorfoseado en asno y no en búho como deseaba. De manera análoga, más adelante, en III, 5, Lucio tiene la posibilidad de saborear unas frescas rosas, sin embargo, acaba retrayéndose de su ávido deseo porque, al recuperar su forma humana, los ladrones podrían darle su merecido. Sea como fuere, se convierte en una verdadera obsesión para Lucio el degustar las rosas, según se comprueba en IV, 1, contexto narrativo en el que los ladrones lo han raptado y llevado a una cueva, morada de estos, al margen de estar presente en otros pasajes como en VII, 3 y X, 6, hasta que Lucio se inicie en los misterios de Isis y Osiris en XI, 2, probando las rosas del silencio, al decir de Baltasar Gracián en El Criticón, o «de razón y prudencia».

Ahora bien, en lo que concierne a Lucio o El Asno de Luciano, le dice Palestra a Lucio que el antídoto que le habrá de permitir recuperar su prístina forma consistirá, claro está, en unas rosas. De esta suerte, Lucio, cuya risa se había convertido en un rebuzno, deberá esperar para ello al menos esa noche; o sea, de nuevo otra referencia temporal al igual que sucede en El Coloquio. Incluso la sorpresa expresada por Lucio en lo que atañe a su facultad de raciocinio en forma de animal recuerda la de los perros sabios de El Coloquio. Por tales razones, asistimos a un lugar común respecto a El Asno de oro, III, 4, habida cuenta de que, cuando Andria le llega a explicar a Lucio el remedio para recuperar su forma primigenia, este se asombra, al igual que los perros hermanos Berganza y Cipión, de que pueda conservar su «sentido de hombre». Con todo, se trata de un leitmotiv desarrollado por Apuleyo en otros pasajes, por ejemplo en IV, 1, como fiel reflejo de la obsesión de Lucio por consumir rosas en calidad de paliativo a su errónea y no deseada metamorfosis. Finalmente, Lucio, probando las rosas del silencio, recobrará la facultad de hablar sin rebuznos, según se advierte en El Asno de oro, XI, 2, hasta ordenarse sacerdote de Isis en Roma en una culminación iniciática y ascesis espiritual, con resonancias en sus propias palabras, a las que luego el sacerdote le referirá su «curiosidad sin provecho».

Por otra parte, en El Coloquio cervantino se formula este recobro de la forma primigenia a modo de profecía de la bruja, con huellas del Juicio final 
(san Mateo, XXIV, 44) ${ }^{65}$. De hecho, la profecía enunciada por una suerte de sibila o maga, en una adivinación, pronóstico o enigma como en El Coloquio, está presente en El Asno de oro, II, 2. E incluso dicho leitmotiv continúa en II, 3, como se indica en el argumento, en tanto que, en calidad de correspondencia intertextual respecto a su modelo apuleyano, Cipión llega a poner en tela de juicio estas profecías más cercanas a las patrañas de viejas, con una evocación de los versos proféticos que revisten variantes no demasiado significativas. Es más, Berganza, mediante una técnica recolectiva en la que recuerda a las tres brujas referidas, manifiesta que las metamorfosis y demás vicisitudes fabulosas de los dos hermanos responden a un sueño ${ }^{66}$, motivo tan cervantino como heredero, en fin, de la tradición apuleyana-lucianesca.

\section{Nuevas tropelías del mago Cervantes: a PROPÓSito DE CueVAS, BRUJERÍAS Y FILOSOFÍAS ÉPICO-NOVELESCAS}

Como estamos viendo, resulta visible la amplia imaginería estética identificable en El Coloquio, destacando, además del antídoto de las rosas, otros referentes simbólico-visuales; entre ellos, la categoría espacial de la cueva en la que los gitanos decidieron esconder al perro Berganza y que tiene su correlato en El Asno de oro, V, 1, y de manera análoga, en IV, 2, en su argumento, en correspondencia con el texto cervantino ${ }^{67}$. Sea como fuere, en dicho contexto intertextual, entre ladrones, pícaros y toques de hechicería con metamorfosis incluida, la tropelía o engaño mediante juegos de manos por parte de los tropelistas constituye un artificio de magia que le permite al mago Cervantes, al trasluz de otro reconocido en la tradición clásica, Apuleyo, «mostrar con propiedad un desatino»; o lo que es lo mismo, al margen de imitaciones concretas, Cervantes encuentra en El Asno de oro, como también en la ficción de Luciano, un método para su artefacto narrativo sustentado en el principio conceptual de la verosimilitud. De hecho, el oficio del tropelista asociado al juego de manos y otros trucos de magia está prácticamente en el arranque de El Asno de oro, I, 1, como pudo percibir Cervantes, al tiempo que se apunta la categoría espacial a la que acuden los personajes, el mesón, que reaparece en I, 3, como la venta en El Quijote, o el arte de esgrima parodiado en el episodio de los cueros de vino, con puntos de encuentro respecto a la Filosofía de las armas de Jerónimo de Carranza. Por lo demás, el motivo de la esgrima, conceptualizado por López de Cortegana en su traducción, se vuelve a repetir en El Asno de oro, IV, 3, al hilo de un cuento que viene a relatar uno de los ladrones motivado por el secuestro en Plateas de

65. Cervantes $(2010,705)$.

66. Cervantes $(2010,716-718)$.

67. Cervantes $(2010,701-703)$. 
Democares en el que uno de ellos se disfrazó mediante «una graciosa industria» con un cuero de loba.

De forma similar, en consonancia con la magia y los hechizos, Cervantes recurre en El Coloquio a diferentes principios fabulosos y esotéricos de calado simbólico tales como la alquimia, la piedra filosofal o la cuadratura del círculo, como se trasluce en el diálogo entre el alquimista y el matemático, al decir de Berganza ${ }^{68}$; hechos fabulosos todos ellos, por otra parte, en consonancia con los ensalmos y variados rituales, prodigios y encantamientos en Luciano; por ejemplo en Cuentistas o El descreído, con un catálogo de serpientes, prefiguración añadida del de La Farsalia de Lucano, de notoria recepción épico-novelesca como en el Hércules animoso de Juan de Mal Lara ${ }^{69}$. En cualquier caso, como pudo percatarse Cervantes, se trata de un relato en el que no faltan las alusiones a perros rabiosos y hasta hombres y cuentos que muerden en las palabras de Filocles dialogando con Tiquíades. Por último, Cañizares acabará narrando con sumo detalle los complejos rituales de brujería $^{70}$, mientras que Berganza le llegará a pedir a Cipión que le permita filosofar un rato como un impasse respecto a su laborioso servicio al mercader en Sevilla ${ }^{71}$.

Pues bien, esta crítica cervantina a los vicios de la filosofía, con censura incluida, se muestra afín a los relatos antiguos de tradición lucianesca, como se reconoce en la Historia verdadera y los sucesos reales de su vida en primera persona. Por ello, en su primera parte, plantea al lector un pacto de ficción sustentado en historias fabulosas para que se haga copartícipe de la ficción que se propone por más disparatada que pudiera resultar. A modo de correspondencia intertextual, en el relato cervantino, tras varias alusiones a las murmuraciones soterradas de los filósofos y a los latines del sabio Berganza como contrapunto entre latinistas y romancistas, se llega a aludir a los latines y a los asnos, al tiempo que destaca la evocación de los filósofos cínicos, por tanto otras vidas de perros, y su principio dialéctico de la parresía; así el caso de Menipo y su viaje a la luna en el relato lucianesco Icaromenipo o Menipo en los cielos. Por lo demás, reviste igualmente interés el guiño cervantino a la cola o rabo, en una crítica a la estructura narrativa lineal de la novela picaresca a la manera de Mateo Alemán y sus dos partes del Guzmán de Alfarache, además de los continuos silencios e interrupciones del género ${ }^{72}$. Tanto es así que se trata de una directriz conceptual que se propuso desarrollar Cervantes más adelante a modo de metadiscurso filosófico o metafilosofía, si se quiere ${ }^{73}$, incluso con implicaciones cínicas por parte de los falsos murmuradores en el discurso de la vida de Cervantes entre la realidad y la ficción ${ }^{74}$;

68. Cervantes $(2010,732)$.

69. Mal Lara (2015b).

70. Cervantes $(2010,707)$.

71. Cervantes $(2010,674-675)$.

72. Cervantes $(2010,676-677)$.

73. Cervantes $(2010,678)$.

74. Cervantes $(2010,680-681)$. 
es decir, en el Viaje del Parnaso a propósito de la capa de la virtud con la que es canonizado por Apolo y las Musas en el Parnaso.

Sea como fuere, en El Coloquio se identifica sobre este particular un adagio de notable tradición desde Erasmo, 'conviene callar si hay dinero de por medio', mientras que al buey ${ }^{75}$, en otro contexto, por imitación respecto a Odisea, X, 98, se había referido Luciano en su Icaromenipo. En otros términos, los refranes, dichos y sentencias proverbiales, tan gratos a Cervantes como continuador de la práctica paremiológica de filiación erasmiana, se identifican en El Asno de oro, con especial gusto y regusto en su traducción por López de Cortegana; por ejemplo, en el cierre de IX, 6, en palabras de Lucio. De manera análoga, la crítica cervantina a los jueces comprados se encuentra en El Asno de oro, X, 6, en concreto, en el episodio de las fiestas de Corinto en las que acaba participando Lucio.

Ahora bien, estos perros sabios de Cervantes no solo se parecen a los filósofos cínicos, como Menipo en el Icaromenipo lucianesco, sino que pueden llegar a confundirse con auténticos $\left\langle\right.$ predicadores» ${ }^{76}$; seguramente en un apunte crítico a la atalaya de la vida ${ }^{77}$, desde donde sermonea a los lectores el pícaro Guzmán de Alfarache. Con todo, no cabe olvidar, al tiempo, las oraciones a la Luna que llega a consagrar Lucio durante su iniciación mistérica en la religión de Isis y Osiris, que leyó Cervantes en su Apuleyo moralizado y ejemplar, como también Lope de Vega o Góngora ${ }^{78}$, entre otros ingenios de nuestras letras áureas. De hecho, se recuerda en el argumento del libro XI, con apuntes a la «historia verdadera», «los secretos de la filosofía» y los misterios de Egipto, mientras que en paralelo a la representación temática de la luna y los sueños por Luciano en sus Relatos verídicos o Historia verdadera, en El Asno de oro se halla, una vez más, esta resonancia, al igual que en el argumento de XI, 1. Finalmente, degusta Lucio las deseadas rosas y vuelve a su naturaleza de hombre, según se refiere en el argumento de XI, 2 , episodio en el que se aduce el término «quijote», en una imaginería procedente de la esgrima. La magia, en cualquier caso, daría sentido a este desatino enderezado por Cervantes desde el principio de verosimilitud como eficaz método de ars narrandi: los perros hablan y hasta discurren sobre temas filosóficos y de varia temática ${ }^{79}$.

En resumidas cuentas, hemos asistido a sucesivas metamorfosis y transformaciones desde Apuleyo y Luciano a Cervantes al hilo axial de unas vidas de perros, con asnos incluidos, en imágenes e instantáneas en aras de la comprensión del imaginario de la vida picaresca de la ciudad de Sevilla y de sus protagonistas actantes. Se ha demostrado especialmente en El Coloquio

75. Para las implicaciones simbólicas entre buey y asno, con pervivencia de El Asno de oro de por medio, véase la nota 27.

76. Cervantes (2010, 665-666).

77. U otra extraña forma de vida, por mencionar a un excelente novelista actual y mejor catador, si cabe, de la narrativa de Cervantes: Enrique Vila-Matas.

78. Preparo un artículo sobre la cuestión.

79. Cervantes $(2010,650)$. 
de los perros, con una notoria inclinación hacia una etapa de conversión espiritual, en el caso de López de Cortegana, autor de la traducción romanceada de El Asno de oro que leyó Cervantes, y hasta en el mismo autor alcalaíno en los últimos compases de su vida, como le habría de criticar Avellaneda en El Quijote apócrifo entre burlas y veras. Según se ha podido comprobar, al servicio del análisis planteado me he servido de categorías conceptuales tales como autorreferencialidad y autor caché en un marco de sociabilidad estética. De hecho, no es de extrañar que este proceder técnico circunscrito a la autorrepresentación en el discurso con el objeto de recrear los cambios vitales y avatares existenciales del creador, al igual que en el autor de El Quijote o López de Cortegana, constituya un recurrente arquetipo en las estructuras antropológicas del imaginario estético cervantino en la vida y en el arte. Así lo estaba viviendo nuestro escritor a nivel de experiencia humana, con el apuleyanismo hispalense al fondo, y además lo había leído bajo el arrope de la ficción en modelos canónicos de la Antigüedad clásica, tanto en las Metamorfosis o en El Asno de oro de Apuleyo, complementarias a las Metamorfosis de Ovidio, como en los relatos y diálogos de Luciano, entre la realidad y la ficción, la vigilia y el sueño.

Por ello, Cervantes sabía que la vida del ser humano, o su representación ficticia en un animal al modo de estos perros (asnos) filósofos, como también las fábulas esópicas editadas al cuidado del humanista Diego Girón, estaba sujeta a un continuo proceso de cambio e inevitable impermanencia; y es que se producía bien en la ficción literaria o en la realidad, como un perenne proceso de búsqueda y crecimiento personal a modo de perpetuum mobile. Tanto es así que se materializaba, con frecuencia, en constantes filosóficas y ontológicas, en una suerte de interrogantes para estas vidas de perros o de asnos; o sea, sé lo que eres o sé lo que quieres ser, con guiños pindáricos en la tradición literaria clásica hasta la construcción cambiante identitaria de don Quijote y su acabamiento final, y sobre todo en la resurrección en el diálogo entre El casamiento engañoso y El Coloquio de los perros, según he puesto de relieve en estas páginas. En la urdimbre y trama de don Quijote, el ingenioso caballero andante acabará volviendo a su condición de hidalgo, pero con transformación inmortal en calidad de leyenda o personaje legendario para la posteridad literaria.

En definitiva, queda todavía mucho por decir siguiendo la recta senda de ejemplares vidas de arte a la cervantina ${ }^{80}$, aunque sean vidas de perros, porque, como leyó Cervantes en la traducción de López de Cortegana, todos llevamos a cuesta un asno y no precisamente de oro; algunos incluso de plata, como el asno de plata de Juan Ramón Jiménez, gran lector, por cierto, de Cervantes ${ }^{81}$. Por ello y a la luz del imaginario de Apuleyo y Luciano, rebuzne el pícaro entre metamorfosis y transformaciones para vidas de perros. 


\section{BIBLIOGRAFÍA CITADA}

Apuleyo. 2019. El Asno de oro (Medina del Campo, 1543), ed. Francisco J. Escobar. México: Frente de Afirmación Hispanista, A. C.

Arce de Otálora, Juan de. 1995. Coloquios de Palatino y Pinciano, ed. José Luis Ocasar Ariza. Madrid: Turner.

Blanco, Mercedes. 2012. Góngora o la invención de una lengua. León: Universidad.

Brioso, Héctor. 1998a. Sevilla en la prosa de ficción del Siglo de Oro. Sevilla: Diputación.

Brioso, Héctor. 1998b. Sevilla en la literatura del Siglo de Oro: el sentimiento anticiudadano barroco. Sevilla: Ayuntamiento, Área de Cultura.

Brioso, Héctor. 2020. «El desdichado era poeta: la caricatura del mal dramaturgo en El Coloquio de los perros de Miguel de Cervantes». Arte Nuevo 7: 1-39.

Cárdenas-Rotunno, Anthony J. 2016. «De perros y asnos: Cervantes y la tradición». Anuario de Estudios Cervantinos 12: 199-212.

Cervantes, Miguel de. 1991. Viaje del Parnaso. Poesías varias, ed. Elías L. Rivers. Madrid: Espasa-Calpe.

Cervantes, Miguel de. 1998. Don Quijote de la Mancha, dir. Francisco Rico. Barcelona: Instituto Cervantes - Crítica.

Cervantes, Miguel de. 2010. Novelas ejemplares, ed. Jorge García López. Barcelona: Crítica, 2. ${ }^{\mathrm{a}}$ ed.

Cervantes, Miguel de. 2014. La Galatea, eds. Juan Montero, Francisco J. Escobar y Flavia Gherardi. Madrid - Barcelona: Real Academia Española - Galaxia Gutenberg - Círculo de Lectores.

Cervantes, Miguel de. 2019. La tía fingida, ed. Adrián J. Sáez. Madrid: Cátedra.

Cervantes de Salazar, Francisco. 2012. Apólogo de la Ociosidad y el Trabajo de Luis Mexía, glosado y moralizado por Francisco Cervantes de Salazar, ed. Consolación Baranda. Salamanca: Ediciones Universidad de Salamanca.

Darnis, Pierre. 2014. "Génesis de la picaresca, absolutismo e individuo en las Vidas de Lázaro de Tormes y Guzmán de Alfarache». Creneida. Anuario de Literaturas Hispánicas 2: 316-348.

Darnis, Pierre. 2015. «El ingenioso hidalgo don Quijote (1605), satire ménippéenne (Prosas nuevas -V-: cartas, relaciones, "Lazarillos", "Guzmanes" y "Quijotes")». Studia Aurea. Revista de Literatura Española y Teoría Literaria del Renacimiento y Siglo de Oro 9: 113-146.

Darnis, Pierre, Elvezio Canonica, Pedro Ruiz Pérez y Ana Vian Herrero, eds. 2017. Sátira menipea y renovación narrativa en España: del lucianismo a Don Quijote. Córdoba - Burdeos: Editorial de la Universidad de Córdoba - Presses Universitaires de Bordeaux.

De Armas, Frederick A. 1976. The Invisible Mistress: Aspects of Feminism and Fantasy in the Golden Age. Charlottesville, Virginia: Biblioteca Siglo de Oro.

Delicado, Francisco. 2013. La Lozana andaluza, eds. Folke Gernert y Jacques Joset. Madrid: Real Academia Española.

D’Onofrio, Julia. 2018. «De las orejas a la cola. Deleite, parodia y autoconocimiento en las representaciones simbólicas del asno y el mono en el Quijote (II, 24-28)». Anales Cervantinos 50: 105-135. https://doi.org/10.3989/anacervantinos.2018.004.

Egido, Aurora. 1994. Cervantes o las puertas del sueño. Estudios sobre «La Galatea», «El Quijote» $y$ «El Persiles». Barcelona: PPU.

Escobar, Francisco J. 2000. «Una fuente italiana desconocida para un poema de Gutierre de Cetina. La Historia de Psique, traducida». Archivo Hispalense 253: 73-80. 
Escobar, Francisco J. 2002. «Versiones poéticas del mito. La Historia de Psique, traducida». En El mito de Psique y Cupido en la poesía española del siglo XVI, 47-76 y 175-201. Sevilla: Secretariado de Publicaciones de la Universidad.

Escobar, Francisco J. 2007. «El binomio formonsitas / pulchritudo en El Persiles. De la belleza corpórea a la categoría simbólico-mítica». Anuario de Estudios Cervantinos. Cervantes entre dos Siglos de Oro. De «La Galatea» al «Persiles» 3: 233-256.

Escobar, Francisco J. 2008. «Nuevos datos para la lectura de la historia de Croriano y Ruperta (Persiles, III, 17): a vueltas con los aspectos mítico-retóricos». En Humanismo y pervivencia del mundo clásico IV.1. Homenaje al profesor Antonio Prieto, eds. José M. ${ }^{a}$ Maestre, Joaquín Pascual y Luis Charlo, 287-302. Madrid - Alcañiz: CSIC - Instituto de Estudios Humanísticos.

Escobar, Francisco J. 2015a. «Nouveaux renseignements sur Fernando de Herrera et l'Académie sévillane dans Philosophía de las armas, de Jerónimo de Carranza». En La Renaissance en Europe dans sa diversité. III. Circulation des hommes, des idées et des biens, héritages, eds. Lioudmila Chvedova, Michel Deshaies, Stanislaw Fiszer y Marie-Sol Ortola, 289-303. Nancy: Université de Lorraine, Groupe «XVI ${ }^{\mathrm{e}}$ et XVII siècles en Europe».

Escobar, Francisco J. 2015b. «Dos textos desconocidos de Jerónimo de Carranza a propósito del XI Conde de Niebla y Mateo Vázquez (con unas notas sobre Hernando de Vega)». En El Duque de Medina Sidonia: mecenazgo y renovación estética, eds. José Manuel Rico García y Pedro Ruiz Pérez, 119-142. Huelva: Servicio de Publicaciones de la Universidad.

Escobar, Francisco J. 2018a. «Materiam superabat opus: Cervantes, cautivo lector de Rufo (al trasluz de la modalidad épico-novelesca en La Austríada y los Apotegmas)». Creneida 6: 146-198.

Escobar, Francisco J. 2018b. «Resuene el cuento de Silerio: Psalle et sile o intersecciones dialogísticas en La Galatea (con tres variaciones y rondó final)». E-Spania 29: 1-43.

Escobar, Francisco J. 2018c. «Comparatismo interdisciplinar. Literatura y música en $L a$ Galatea de Cervantes». En «El Quijote» y la música en la construcción de la cultura europea, ed. Begoña Lolo, 81-115. Madrid: Universidad Autónoma de Madrid.

Escobar, Francisco J. 2018d. Vidas de arte en el humanismo hispalense. De Nebrija a Góngora, pról. Jaime Garau. México: Frente de Afirmación Hispanista, A. C.

Escobar, Francisco J. 2019a. «Ut musica poesis o música de soledades en La Galatea (con notas cervantinas sobre etología humana)». En Cervantes \& Shakespeare. 400 anos no diálogo das Artes, eds. Annabela Rita, Mário Vítor Bastos e Renato Epifânio, 1-15. Lisboa: Theya Editores - IECCPMA.

Escobar, Francisco J. 2019b. «Entre baladas de primavera. El asno de plata, de Juan Ramón Jiménez en su paisaje sonoro». Cuadernos de investigación musical 8: 115-135.

Fernández de Oviedo, Gonzalo. 1992. Historia general y natural de las Indias, ed. Juan Pérez de Tudela Bueso. Madrid: Atlas.

García Gual, Carlos. 2013. «Novelas de metamorfosis. Apuleyo y Luciano y sus ecos hispánicos del siglo XVI». En La «metamorfosis» de un inquisidor: el humanista Diego López de Cortegana (1455-1524), eds. Francisco J. Escobar, Samuel Díez y Luis Rivero, 257-270. Sevilla - Huelva: Universidad de Sevilla - Universidad de Huelva Ayuntamiento de Cortegana.

Gil, Juan. 1986. «Apuleyo y Delicado. El influjo de El Asno de oro en La Lozana andaluza». Habis 17: 209-219.

Gómez Canseco, Luis M. a . 2013. «La Sevilla odiada de Mateo Alemán». Boletín de la Real Academia Sevillana de Buenas Letras. Minervae Baeticae 41: 107-126.

Gracián, Baltasar. 1990. El Criticón, ed. Santos Alonso. Madrid: Cátedra. 
Gracián, Baltasar. 1993. Agudeza y arte de ingenio, ed. Emilio Blanco. Madrid: Turner.

Horozco, Sebastián de. 1994. Libro de los proverbios glosados, ed. Jack Weiner. Kassel: Reichenberger.

Jiménez Heffernan, Julián, ed. 2008. La tropelía: hacia «El coloquio de los perros». Madrid: Artemisa.

Laercio, Diógenes. 2009. Vidas de filósofos cínicos - La secta del perro, ed. Carlos García Gual. Madrid: Alianza Editorial, 3. ${ }^{\mathrm{a}}$ reimp.

López de Úbeda, Francisco. 2012. Libro de entretenimiento de la pícara Justina, ed. David Mañero Lozano. Madrid: Cátedra.

López Estrada, Francisco. 2004. «Quixotes en el Apuleyo castellano». En Siglos dorados. Homenaje a Augustin Redondo, ed. Pierre Civil, vol. II, 797-805. Madrid: Editorial Castalia.

Lucero Sánchez, Ernesto. 2019. «El asno del Pensé que en la Filosofía cortesana de Alonso de Barros». Studia Aurea 13: 161-180.

Luciano. 1998. Relatos fantásticos, introd. Carlos García Gual. Madrid: Alianza Editorial.

Luciano. 2013. Historia verdadera, trad. Francisco Socas; ilustr. Juan Socas. Sevilla: Ediciones La Piedra Lunar.

Madroñal Durán, Abraham. 2011. «La segunda parte perdida del Coloquio de los perros, de Ginés Carrillo Cerón». Anales Cervantinos 43: 181-204. https://doi.org/10.3989/ anacervantinos.2011.007.

Madroñal Durán, Abraham. 2012. «Entre novela y entremés: la segunda parte de El Coloquio de los perros». En Novela corta y teatro en el Barroco español (1613-1685). Studia in honorem Prof. Anthony Close, coords. Rafael Bonilla, José Ramón Trujillo y Begoña Rodríguez, 169-184. Madrid: Sial.

Madroñal Durán, Abraham. 2013. La segunda parte del Coloquio de los perros de Ginés Carrillo Cerón. Alcalá de Henares: Centro de Estudios Cervantinos.

Mal Lara, Juan de. 2015a. La Psyche, ed. Francisco J. Escobar. México: Frente de Afirmación Hispanista, A. C.

Mal Lara, Juan de. 2015b. Hércules animoso, ed. Francisco J. Escobar. México: Frente de Afirmación Hispanista, A. C., 3 vols.

Marasso, Arturo. 1954. Cervantes: la invención del Quijote. Buenos Aires: Hachette.

Mascarell, Purificació. 2011. «Lazarillos y metamorfosis. Estudio de las relaciones entre El Asno de oro, el Lazarillo de Tormes y su Segunda parte». Lemir 15: 271-284.

Mejía, Pedro. 1989. Silva de varia lección, ed. Antonio Castro Díaz. Madrid: Cátedra.

Mejía, Pedro. 2004. Diálogos o Coloquios, ed. Antonio Castro Díaz. Madrid: Cátedra.

Molina, Tirso de. 1982. La huerta de Juan Fernández, ed. Berta Pallares. Madrid: Castalia.

Núñez Rivera, Valentín. 2015. Cervantes y los géneros de la ficción. Madrid: Sial.

Ortega Garrido, Andrés. 2014. «De los filósofos antiguos al romano Apuleyo en el Burguillos de Lope de Vega: notas de tradición clásica». Bulletin of Spanish Studies 91 (3): 335-355.

Percas de Ponseti, Helena. 1980. «La Cueva de Montesinos». En El «Quijote» de Cervantes, coord. George Haley, 142-174. Madrid: Taurus.

Pineda, Juan de. 1963-1964. Diálogos familiares de la agricultura cristiana, ed. Juan Meseguer Fernández. Madrid: Atlas.

Rojas, Fernando de. 1993. La Celestina. Comedia o tragicomedia de Calisto y Melibea, ed. Peter E. Russell. Madrid: Clásicos Castalia.

Ruiz Pérez, Pedro. 1996. «Pícaros y mercaderes». Cuadernos Hispanoamericanos 552: 133-136.

Ruiz Pérez, Pedro. 2011. «Sátira, picaresca, novela». Ínsula. Revista de letras y ciencias humanas 778: 10-12. 
Sáez, Adrián J. 2014. «Más sobre Cervantes, Plutarco y los cínicos: una anécdota de Alcibíades y el Coloquio de los perros». Anales Cervantinos 46: 149-160. https://doi. org/10.3989/anacervantinos.2014.009.

Sáez, Adrián J. 2015. «Ecos y referentes clásicos en el Coloquio de los perros de Cervantes». En Humanismo y pervivencia del mundo clásico V.3. Homenaje al profesor Juan Gil, eds. José M. ${ }^{\text {a }}$ Maestre Maestre, Sandra I. Ramos Maldonado, Manuel A. Díaz Gito,

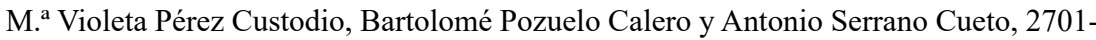
2716. Madrid - Alcañiz: CSIC - Instituto de Estudios Humanísticos.

Sánchez Jiménez, Antonio y Emilio Blanco. 2014. «Machabelo y Maquiavelo: la patraña XX de El patrañuelo (1567), de Timoneda». Studia Aurea 8: 177-193.

Suárez de Figueroa, Cristóbal. 1988. El pasajero, ed. M. ${ }^{a}$ Isabel López Bascuñana. Barcelona: Promoción y Publicaciones Universitarias.

Vega, Lope de. 2001. La viuda valenciana, ed. Teresa Ferrer Valls. Madrid: Clásicos Castalia.

Vega, Lope de. 2005. Rimas humanas y divinas del licenciado Tomé de Burguillos, ed. Juan Manuel Rozas y Jesús Cañas Murillo. Madrid: Clásicos Castalia.

Vega, Lope de. 2016. El peregrino en su patria, ed. Julián González-Barrera. Madrid: Cátedra.

Vélez de Guevara, Luis. 1980. El diablo cojuelo, eds. Ángel R. Fernández González e Ignacio Arellano. Madrid: Castalia.

Vivar, Francisco. 2016. «El arte de la metamorfosis y el arte de la novela: Apuleyo y Cervantes». eHumanista 33: 318-330.

Recibido: 8 de diciembre de 2019

Aceptado: 31 de mayo de 2020 
